\title{
ZOMBIES IN TONDELA: WATCHING I'LL SEE YOU IN MY DREAMS (2003)
}

\author{
Rita Martins, José Duarte, Ana Daniela Coelho \\ University of Lisbon Centre for English Studies (ULICES) \\ anna.rita.mart@gmail.com \\ joseaoduarte@gmail.com \\ anaalcobiacoelho@gmail.com
}

Recibido: 30-06-2015

Aceptado: 13-11-2015

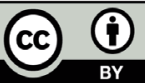

\begin{abstract}
Monsters have attracted our imagination throughout times, even in an apparently rational and pragmatic age such as ours. Being one of the monsters of the new millennium, the zombie is now a permanent figure of popular culture, both embodying society's most terrible fears and exploring audience's desire for violent cathartic experiences. Of African origins, the zombie has been popularised by American cinema and spread across cultures and media. Although with no great tradition of horror, Portugal also has an example of the zombiemania that seems to have overtaken the world, the short film I'll See You In My Dreams (2003, Dir. Miguel Angél Vivas, Prod. Filipe Melo). This article aims at questioning the concept of monster in general terms, then look at the evolution of the zombie as a monstrous figure in particular and, finally, analyse that which is considered the first Portuguese zombie film, contextualising it in relation to global zombie representations.
\end{abstract}

Keywords: Zombie, Monster, Portuguese Cinema, Filipe Melo, Miguel Angél Vivas

\section{Resumo}

Os monstros têm atraído a nossa imaginação ao longo dos tempos, mesmo numa época aparentemente racional e pragmática como a nossa. Um dos monstros do novo milénio, o zombie é uma figura constante da cultura popular, cristalizando os medos mais terríveis da sociedade e explorando o desejo das audiências por experiências catárticas violentas. De origem africana, o zombie foi popularizado pelo cinema ameri- 
cano, tendo-se espalhado a diferentes culturas e meios. Ainda que sem grande tradição de terror, Portugal tem também um exemplo do fenómeno de zombiemania que parece ter tomado conta do mundo, a curta I'll See You In My Dreams (2003, Real. Miguel Angél Vivas, Prod. Filipe Melo). Este artigo tem como objectivo questionar o conceito de monstro, olhar para a evolução do zombie enquanto figura monstruosa e, finalmente, analisar aquele que é considerado o primeiro filme de zombies português, contextualizando-o relativamente a representações globais do zombie.

Palavras-Chave: Zombie, Monstro, Cinema Português, Filipe Melo, Miguel Angél Vivas

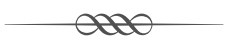

\section{INTRODUCTION: ON MONSTERS}

Today monsters thrive. We see them everywhere, on television, at the movies, in novels, comic books, and videogames, among others. It is almost as if an invasion has taken place, one which has made these figures no less terrifying but seemingly more familiar. From ghosts to witches, cyborgs to aliens, vampires to the ever more popular zombies, and even dinosaurs, monsters seem to hold a special place in modern audiences' collective imagination. However, when speaking about monsters it is clear one might be referring to a variety of creatures or supernatural beings, but also to very human characters whose actions may be described as hideous, thus making them monsters to the viewers and/or readers. Before proceeding to the analysis of the representation of monstrosity depicted in the short film I'll see you in my Dreams, it is important to consider what is being referred to when we talk about monsters.

The interest in monsters is not a modern phenomenon, quite the contrary it has always been there throughout humankind's history. In the classical period centaurs, Cyclops and sirens, among others, were a part of the collective imaginary. These beings, which were part human, part animal, are found in mythological tales, such as the one about Theseus and the Minotaur, and were often linked to the Gods themselves. ${ }^{1}$ Later, although still fascinated by these ancient monsters, the medieval period paid special attention to

1 In Homer's Odyssey, for instance, the man-eating Cyclops Polyphemus is fathered by Poseidon, which is why after Ulysses blinds him, the sea God curses the hero to wander around the oceans. 
witches, werewolves and ghosts or spirits, in short to the so-called supernatural monsters. The Middle Ages were a particularly interesting time in the study of monstrous creatures due to its concern in understanding, locating and justifying (within the Christian religion) the existence of these beings. It was during this period that many theories around what is now known as Monster Studies ${ }^{2}$ were first developed through the works of St. Augustine and Isidore of Seville (c. 560-636), for example.

In the field of Monster Studies, there is considerable research on the etymology of the word «monster», which derives from the Latin monstrum or monstrare, meaning 'to display' or 'to reveal through the sight' and also 'to expose'. Monstrare can also be related to 'to teach' in the sense of instructing what the most appropriate behaviour is. In addition, monstrare derives from monere, 'to warn', 'to announce' or 'to alert'. Therefore, by looking at its etymological origin, there seems to be a clear association between the word monster and sight; monsters show, expose, and reveal something to those who see them. They seem to draw our eye to their abnormality or otherness that simultaneously lure and repulse the beholder. What is the monster trying to show though?

In its abnormal shape the monster contains more substance, more details, ${ }^{3}$ than any other common body whether it is because of its extra-ordinary features or due to its fantastic nature. Symbolically what the monster shows is beyond the material, it brings to light that which is veiled, whether it is the darkest side of Man or God's will. In Monstros (2006), José Gil claims the fantastic body of the monster mirrors a hidden reality that cannot be decoded, but which captivates the one who sees it:

O Monstro é, ao mesmo tempo, absolutamente transparente e totalmente opaco. Ao encará-lo, o olhar fica paralisado, absorto num fascínio sem fim, inapto ao conhecimento, pois este nada revela, nenhuma informação codificável, nenhum alfabeto conhecido. E, no entanto, ao exibir a sua deformidade, a sua anormalidade - que normalmente se esconde - o monstro oferece ao olhar mais do que qualquer coisa jamais vista. (...) O seu corpo difere do normal na medi-

2 The term «Monster Studies» has been used by some researchers to refer to the study of monsters. Other terms include «Monster Theory» as suggested by Jeffrey Jerome Cohen (ed.) in Monster Theory: Reading Culture (1996). In addition, there is also the older term «teratology», which was used primarily to refer to the study of unnatural (or monstrous) births. Bearing in mind that in the academia this field of study is fairly recent (it can hardly be said to have begun in 1996), the proper term when discussing this area is still very much a source of debate. For coherency purposes, in this paper we shall only use «Monster Studies», which is the most commonly used term in this field of studies.

3 When authors like Isidore of Seville tried to classify monsters, mutilation, absence of members or organs were regarded as good criterion as well as the presence of extra parts. 
da em que ele revela o oculto, algo de disforme, de visceral, de «interior», uma espécie de obscenidade orgânica. O monstro exibe-a, desdobra-a, virando a pele do avesso, e desfralda-a sem se preocupar com o olhar do outro; ou para o fascinar (...). (2006: 78)

By unveiling that which is usually withheld, the monster serves a very specific purpose: to allow Men to think about themselves and their actions. José Gil has claimed that Mankind needs monsters to become human (2006: 82), so in this sense monsters show their human beholders what they (most likely) do not wish to become and can be understood, like the etymology of the word «monster» suggests, as warnings of what will happen if we choose a particular course of action.

However, there are other interpretations as to the presence of monsters in contemporaneity. According to Stephen Asma, in On Monsters. An Unnatural History of our Worst Fears, «To be a monster is to be an omen. Sometimes the monster is a display of God's wrath, a portent of the future, a symbol of moral virtue or vice, or an accident of nature» (2009: 13).

Hence, on the one hand, the monster can be understood as a portent of a future catastrophe or the will of (the) God(s), especially in the case of monstrous births. Monstrous birth is the term often associated to children who were born with physical deformities. Whether with a certain body part outside the bounds of the common course of nature or with an excess of limbs, body hair or any other feature(s), these beings were often regarded as signs of the divine, especially in the medieval period. On the other hand, according to a tradition, which prevailed up until the $18^{\text {th }}$ century, the birth of monsters was linked to the moral rottenness of the mothers. In fact, there was a direct relation between monstrous births and the corruption of the female embryo. The depravity or immorality of the mother was considered to be one of the reasons why there were such monsters so if the woman in whose body the child was conceived and carried was impure, that sin would be made visible through the birth of a monster. Female corruption affects the body of the embryo itself, making it monstrous. The child would then show to all (monstrare) the sinful soul of the mother, thus becoming a symbol of a moral vice.

When discussing the existence of different monsters, it is important to bear in mind two different types of races: the monstrous races and the fabulous races. The first bore some semblance to human beings, like the Monopods with only one leg centred in the middle of the body and a large foot or the Cynocephali with man-like bodies and dog heads, but whose nature (animal 
or human) was undetermined. According to medieval beliefs, these peoples lived in the extreme corners of the known world. The fabulous races included fantastic animals, like dragons, unicorns, gryphons, manticores, and so on. These beings were the result of a combination of different animals, such as the gryphons with the head and wings of an eagle and the body of a lion, or of a combination of an animal with a human body, like centaurs with human-like torsos but the body of a horse. According to Gil, fabulous races serve a different aim since they are neither solely symbolical nor real, but have multipurpose, «Têm, portanto, uma função polivalente, múltipla: permitem, claro, pensar a humanidade do homem, mas permanecem sempre secretamente aberrantes, conservando viva a suspeita quanto a essa humanidade» (2006: 55).

Finally, it is important to consider one of the most relevant issues in Monster Studies: how can we define monster or the monstrous? According to the Merriam-Webster online dictionary a monster is «1. a: an animal or plant of abnormal form or structure; b: one who deviates from normal or acceptable behavior or character; 2: a threatening force». Although this definition seemingly covers some ideas connected to monsters, namely their out-of-the-ordinary shape and/or behaviour as well as the danger brought about by their presence, it leaves out important issues. How can a casual observer distinguish between the 'natural' abnormal form of a plant and a 'monstrous' abnormality? Simply put, how can we know a monster if or when we see one?

In the introduction to The Ashgate Research Companion to Monsters and Monstrous, Asa Simon Mittman claims that «[...] the monstrous does not lie solely in its embodiment (though this is very important) nor its location (though this is, again, vital), nor in the process(es) through which it enacts its being, but also (indeed, perhaps primarily) in its impact» (2013: 7). On the same wavelength, Stephen Asma states: «An action or a person is monstrous when it cannot be processed by our rationality, and also when we cannot readily relate to the emotional range involved» (2009: 10). In both definitions, the physicality of the monster seems to take second place. Nevertheless, as mentioned by Mittman, its body is very important and if one thinks about the zombie in particular, then its physical appearance, the decay of the dead body, its discoloration and consequent decomposition, is crucial. Echoing the question posed in The Ashgate Research Companion to Monsters and Monstrous, even though physical abnormality or oddness is one of the monster's most obvious and recognisable markers, is it actually possible to pin down the monstrous in terms of physicality? In fact, that which is monstrous in one 
culture or time might not be and often is not so in a different culture or time, i.e. others' Other might not be our Other. The monster thus seems to elude such limiting definitions; it is not confined to physical or geographical parameters, «it defies the human desire to subjugate through categorization» (Mittman, 2013: 7). In addition, we continually redefine the monstrous, which makes an inclusive definition hard to achieve.

\section{ZOMBIE: THE MONSTER WITHIN US}

As stated above, monsters serve mankind's need to define itself and, at the same time, exorcize its fears. In the last few years no other monster has served this double purpose better than the zombie. The living-dead is one of the oldest mythical figures created by man, present not only in western culture but spread all around the world. Its omnipresence reveals humankind's fascination with fantastic and extraordinary creatures but first and foremost our contradictory relationship with our own limitations, death being the most overwhelming of such boundaries. Simultaneously alive and dead, the living-dead has haunted Man's imagination for centuries, materializing in different fantastic and monstrous creatures among which are the vampire, the ghost and the zombie. Although sharing the same basic features - to the point of a distinction between these creatures being in some cases impossible to establish -, some undead monsters, such as the vampire or the ghost, have been delineated first by means of «real» testimonies and later by fiction, both in literature and in cinema. On the contrary, the relatively recent affirmation of the zombie as an independent monster makes it a unique case among the pantheon of the living-dead, a singularity enhanced by its connection with cinema. This cinematic quality has even led critics such as Kyle Bishop to claim it as a celluloid monster:

In addition to being derived from mythology, legend, and the imagination, zombies also have close ties to other, more literary monsters. They belong to a diverse class of creatures that cross the metaphysical line between life and death, where a strong sense of the uncanny inspires unease and fear. But whereas ghosts, vampires, and golems have been a part of storytelling for thousands of years, the zombie is a relatively modern invention. Their lack of emotional depth, their inability to express or act on human desires, and their primarily visual nature make zombies ill suited for the written word; zombies thrive best on screen. (2006: 200) 
However, the zombie is not limited to its cinematic life, one established during the golden age of the Hollywood's studio system. In fact, its spread across media particularly during the last few years is a proof of the zombie's adaptability and, more significantly, of its adequacy as a metaphor for our greatest fears. An undeniable marker of contemporaneity, zombies are a common figure not only on screen, but also in literature, videogames, comics and in many other cultural products. If we focus on objects produced after 2000,4 we find an increasing number of films among which are titles such as 28 Days Later (2002) and 28 Weeks Later (2007), the series of adaptations from the videogame Resident Evil (2002, 2004, 2007, 2010), the remake of the now classical Dawn of the Dead (2004), George Romero's return to the sub-genre he helped popularise with Land of the Dead (2005), Diary of the Dead (2007) and Survival of the Dead (2009), unusual zombie films such as Fido (2006) and the more commercially orientated and successful Zombieland (2009), Warm Bodies (2013) and World War Z (2013). On television the series Walking Dead (2010-), an adaptation of the graphic novel created by Robert Kirkman, has won both the audience and the critics and paved the way for other zombie products such as iZombie (2015). In the gaming universe, Resident Evil does not stand alone and zombie titles have been growing since the 1990s, including among many others Left 4 Dead (2008, 2009), Call of Duty: Black Ops (2010), Plants Vs. Zombies (2010) and State of Decay (2013).

However the zombie rebirth, or should we say resurrection, is not limited to the screen, even if this was the primordial space of the zombie. It has spread to include novels (such as Pride and Prejudice and Zombies, by Seth Grahame-Smith), comics (like the Marvel Zombies series) and even pseudo-survival guides (like Max Brooks' The Zombie Survival Guide and World War Z).

Given the many and varied forms the zombie has taken, its importance in contemporary culture seems evident. Particularly open to allegory, the zombie has become not only a mirror where our most terrible individual fears are displayed, but also a reflection of our society as a whole, as journalist and cinema critic Kathi Maio remarks: «What is a more common component of cinematic zombie fables over the last seventy years or so is their penchant for allegory. Zombie plots have been used to comment upon everything from the exploitation of the working class to the perils of pollution to the existential

4 Defined by some critics as the beginning of the modern zombie renaissance (see Kyle Bishop, «Dead Man Still Walking: Explaining the Zombie Renaissance»). 
isolation of modern man to the brain-numbing dangers of a consumer society» (2007: 92).

This allegorical nature of the zombie is entwined with its history and in order to comprehend the monster a brief look into its origins is needed.

From HAITI TO ROMERO: THE LIFE OF THE MONSTER

The origins of the zombie as one of the undead creatures are lost in time and interwoven with those of the vampire, the ghost or the ghoul. However, the zombie as we now come to know it is a product of the $20^{\text {th }}$ century, created in great part by American cinema in the 1930s and 1940s. Although a part of the horror genre such as it was then developed in Hollywood, this modern zombie is mostly an adaptation of the zombie from the Haitian vodun religion. From a primitive concept bred in the heart of Africa and taken along with the slaves, the vodun developed as a religion in the sugar plantations of the Caribbean colony. ${ }^{5}$ From there it passed on to the United States, especially as the unstable life in Haiti during the independence war led settlers to seek refuge on the American East Coast. It is therefore in Haiti that the modern concept of zombie seems to take form, although it is still very different from our contemporary notion. In Haiti, according to the vodun religion, the human soul has a double nature. ${ }^{6}$ This double nature of the soul allowed for one of its parts to be captured by a vodun priest using imprecise rituals and ingredients, and thus create a zombi, i.e. a soulless (disinterred) body who would be forced to work at the command of the priest, either in the domestic space or at the sugar plantations. Among the zombie characteristics appointed by the seminal work of Ackerman and Gautier (1991) are the absence of conscience or memory, the glazed look, the absent or sleepy gaze, nasal voice and the impossibility of eating salt.

In the 1930s, the zombie migrated to another environment, that of cinema where it thrived to become more of a universally recognised figure. A usual presence in the horror genre, the cinematic zombie is at first marked by imprecise boundaries: while in some films it seems close to the Haitian zombie - as in the first zombie feature film White Zombie (1932) or in I Walked With

5 See Ackerman and Gautier (1991).

6 According to Ackerman and Gautier these were the Gros Bon Ange-life force, closer to the Christian notion of soul - and the Ti Bon Ange - a kind of protective spirit. To each of these parts, a number of different functions were attributed, although the researchers did not reach a consensus given the difficulties posed by the many dialects spoken by priests and the need to use translators. 
a Zombie (1943) - in other films it is unclear what differentiates the zombie from other undead creatures - as in The Ghost Breakers (1940). However, as the zombie became more of a cinematic creature, it grew progressively apart from the relatively harmless Haitian figure. Instead the zombie's distinctiveness in the monster pantheon became its insatiable desire for human blood or flesh. This evolution may be seen either as a process of assimilation by similitude (namely with the blood-thirsty vampire) or as a corruption of the image of the Other (given the zombie's origin), seen as savage by the Western culture. Whatever the reason, this became the defining trait of the zombie especially after the film by George Romero, Night of Living Dead (1968). Romero's contribution to the sub-genre includes establishing the basics traits of the modern zombie: ${ }^{7}$ a reanimated dead body deprived of conscience, walking slowly due to the rigor mortis and whose only purpose is to devour human flesh thus infecting others with its condition. However, Romero's greatest innovation was turning the zombie into a vehicle of social criticism, a metaphor for Man's shared sins. In fact, Romero's zombie is more than a simple terror-inspiring monster: he represents indiscriminate and unjustified violence, unfounded prejudice and suspicion towards the Other and the uncontrollable consumerist compulsion that came to define post-modern culture.

After a prolific period lasting approximately 15 years, the sub-genre of zombie film declined and the 1990s brought fewer titles as well as pastiches and parodies. For Kyle Bishop such a decline is a direct result of a period of comparative peace and absence of external threats in the United States, after the end of the Cold War. ${ }^{8}$

The new millennium brought a zombie renaissance, turning the zombie into a popular monster not confined as it had been before to the screen, either in films or videogames. Such a phenomenon can be explained by the growing menace posed by international terrorism as well as an increasing concern (inspired by real events) of the possibility of a global epidemic. Furthermore, given its nature as a mass menace - contrary to other monsters the zombie's danger lies in its numbers and ability to multiply rapidly - and subsequent apocalyptical consequences the zombie became a more realistic threat. As Kyle Bishop puts it: «Because the after-effects of war, terrorism,

7 This contribution includes several films but the emphasis must go to the original trilogy, composed by Night of the Living Dead (1968), Dawn of the Dead (1978) and Day of the Dead (1985)

8 According to Bishop: «Historically, zombie cinema had always represented a stylized reaction to cultural consciousness and particularly to social and political injustices, and America in the 1990s saw perhaps too much complacency and stability for zombie movies to fit the national mood» (2009: 18). 
and natural disasters so closely resemble the scenarios of zombie cinema, such images of death and destruction have all the more power to shock and terrify a population that has become otherwise jaded by more traditional horror films» (2009: 18) The increasing emphasis on the decaying physical aspect of the zombie may also be seen as an exacerbation of the zombie's potential to visually shock an audience already used to images of extreme violence.

In this sense the zombie, as a cathartic monster of absolute destruction, ${ }^{9}$ seems to be replacing other monsters. Its presence is so disseminated that in 2003 it even reached Tondela, a small rural town in the north of Portugal.

I'LL SEE YOU IN MY DREAMS: THE SHORT-FILM

Defined by several critics and academics as the first Portuguese zombie film, I'll See You in My Dreams (2003), produced by Filipe Melo and directed by Miguel Ángel Vivas, is an interesting case in the extensive production on zombie narratives made in the last fifteen years. This is particularly relevant taking into account that, after 9/11, zombies became the most significant monster in cinema, since they «foreground the critical relationships between self and other» in the contemporary world (Schopp \& Hill, 2009: 5), particularly in what concerns issues of monstrosity and humanity. Before exploring these and other themes in the short-film, it is important to centre our attention on the relevance of I'll See You in My Dreams in the Portuguese cinematic context. The film by Melo and Vivas is one of the first films approaching the theme of monstrosity with a clear influence from American horror stories, in particular the case of zombie narrative. ${ }^{10}$

In spite of its low-budget production, when compared to major zombie productions, the film was very successful, especially because after its release, it continued to win prizes in prestigious cinema festivals and competitions: Fantasporto (2004, Portugal), Fantasia Film Festival (2004, Montreal) or Badajoz Short Film Festival (2004, Spain). These are some of the examples where the short-film was successful, winning several prizes in different categories

9 See Lauro and Embry (2008).

10 Another important film in this context is Coisa Ruim (2006), directed by Tiago Guedes and Frederico Serra, a feature film, as opposed to the short film that is being discussed here. Also, as in the case of I'll See You in My Dreams, the story is set in a forest, as Oliveira (2013: 27) notes in his study of Viva and Melo's film. Although it deals with life after death and supernatural phenomena, Coisa Ruim is not however a zombie film. 
(sound, image, narrative). Apart from the artistic recognition, the press praised I'll See You in My Dreams, as well as the academy, mostly in anthologies on zombie films. Books like The Zombie Movie Encyclopedia (Dendle, 2010), Zombie Movies: The Ultimate Guide (Kay \& Brugues, 2012), The Book of the Undead: A Zombie Film Guide (Rowan, 2012) are good examples and all include a reference to I'll See You in My Dreams. More recently, for instance, the shortfilm was subject to an analysis by the researcher Adriano Messias de Oliveira, published in a collection on contemporary Portuguese directors (2013).

Being such a popular film and a significant work of art, nationally and internationally, it is pivotal to understand what makes I'll See You in My Dreams so special when taking into consideration the many zombie films released in the last years.

\section{ZOMBIES IN TONDELA}

The fact that I'll See You in My Dreams is a Portuguese film puts it the margins, but it is also what makes it so interesting in creative terms. A pioneer in Portuguese horror cinema, Filipe Melo, as the producer, was well aware of the limitations and of the possibilities of doing such a film. Contrary to most trashy/horror low-budget zombie narratives, Melo sought to produce a high quality picture by asking Miguel Ángel Vivas to direct the film and wanted to hire Tom Savini - famous for playing roles in horror films -, but he refused. As an alternative, Melo directed his attention towards special effects. In order to create the most realistic zombies possible, the producer contacted SFX Studio, as he mentions in an interview to UZI Magazine - responsible for films like Scary Movie 3 (David Zucker, 2003) or the TV series X-Files (1993-2002). The search for a high-quality studio is proof of Melo's creative vision and seriousness as an artist, but also shows he knew that the experienced crew from SFX Studio would help to improve the final visual quality of the film.

Filipe Melo also contributed to the script, since the original idea of a zombie film was his. His vision was essential to the success of the short-film, since Melo developed the story as homage to the masters of horror cinema, like George A. Romero, Lucio Fulci, Dario Argento, Sam Raimi, among others. ${ }^{11}$ These and other references will be crucial for the spectator to empathize with the film.

11 For instance, the characters' names are references to different horror fillm directors: Lúcio - Lucio Fulci; Sam the Tavern Customer (Manuel João Vieira) - Sam Raimi; Dário the Tavern Keeper (João Didelet) - Dario Argento; Nancy (São José Lapa), Miguel (Rui Unas) or Ana (Sofia Aparício), are cha- 
I'll See You in My Dreams is set in a small rural town placed in a forest ${ }^{12}$ that is inexplicably haunted by a zombie plague. Lúcio (Adelino Tavares) is the only one who can fight them, but even he fails to do so, as the film explores notions of violent behaviour, love and hate, and the question of how human beings are one step away from easily becoming monsters. In this sense, even though the film is set in Portugal - nearby Tondela, Filipe Melo's birthplace, it seems to have a universal appeal, especially because both Miguel Ángel Vivas and Filipe Melo were concerned about creating an international product, from the English title to the horror movie atmosphere.

Among the several directors that influenced Melo's creation, Lucio Fulci seems to play an important role. I'll See You in My Dreams echoes the environment of some of the films by the Italian director, specifically in the way it explores the themes of beauty vs. perversion, or how it creates a particular gore/horror environment, «[a] claustrophobic mise en scène set within houses and damp landscapes which drip with the viscosity of the bodies crawling therein» (McCormack, 2004). Though not as violent as some of Fulci's films, the Portuguese film uses violence and gore in order to inquire into the monstrosity evidenced by the main characters, namely Lúcio, Sam the Tavern Customer or Ana.

THE THING I HATE THE MOST ARE THE FUCKING ZOMBIES: WHO ARE THE REAL MONSTERS?

I'll See You in My Dreams gets its name from a song written in 1924 by Isham Jones, with lyrics from Gus Khan, a popular song that has several versions. ${ }^{13}$ In fact, the opening credits play a version that contrasts with the horror and zombie images, a reference to the dreamy quality of this narrative, which the ending seems to emphasize. The spectator has no clue as to why

racters that recall Lucio Fulci's films, in particular the zombie Gates of Hell trilogy (Paura nella città dei morti viventi, 1980; L'aldilà, 1981 and Quella villa accanto al cimitero, 1981). For a more detailed description of some of Fulci's films see: Balun, Chas (1996): Lucio Fulci: Beyond the Gates, Blackest Heart Books, San Leandro, California.

12 Note the importance of the role played by forests in horror films. As Leo Hickman remarks in an article for The Guardian, «forests are places where hidden dangers and horrifying creatures lurk in the darkness» (2010). This representation seems to track back to the European Middle Ages when forests were regarded as places of great peril where one might be faced with real threats, such as burglars or wild animals, and with fantastic dangers, like demons, witches or other supernatural beings. At the same time, the forest was also a place of initiation as many heroes of romance, like Sir Perceval in Chrétien de Troyes' Perceval, le Conte du Graal (c. 1135-1190), began their adventures in this space.

13 One of which performed by the Portuguese metal band Moonspell, part of the soundtrack of Melo and Viva's film. The cast and crew of I'll See You in My Dreams also recorded the promotional video. 
there is a plague of zombies - a common trait in zombie films -, and seems involved in a nightmarish world. In this sense, the dream proposed by Melo and Vivas is characterized by irony: the title pointing to the world of dreams that are, in fact, nightmares comprised of monsters, humans and zombies.

In the opening scene of the short-film, an allusion to the Western-spaghetti subgenre, we see Lúcio - the anti-hero of the narrative - killing a zombie and saying: «The thing I hate the most in this village are the fucking zombies». In spite of that, Lúcio has a hidden secret: he keeps his zombie-wife, Ana, locked in the basement, possibly because he feels guilty about being responsible for her transformation. At the same time, he still shows some feelings towards her. Nonetheless, Lúcio will get involved with Nancy, a girl he rescues from the hands of Sam the Tavern Costumer, which will make Ana jealous, and this is the starting point of a zombie-hell in town.

Contrary to the dark world presented by the forest, the place where the zombies linger, the tavern seems to be a safe place. Notwithstanding, while the forest is a symbol of our irrational fear and the horror perpetrated by the zombies, the tavern is the site of violence and merciless behaviour, a comment on the monstrosity of humans when confronted with adverse conditions or when safety infrastructures no longer exist. These aspects can be seen both in Sam the Tavern Costumer, who tries to exert physical violence on Nancy so as to have sex with her, or the case of the priest who is bitten by zombies. In both situations Lúcio plays a crucial role: he saves Nancy and kills the priest before he turns into a zombie, which is an interesting comment on a world devoid of any hope or spirituality.

In fact, most of the characters who inhabit this world seem emotionally and spiritually empty, in the sense that they are characterized by acts of revenge, treason, hate, anger and a return to primal instincts. The men are represented by monstrous acts: Lúcio's anger towards Ana and his act of throwing Nancy at the zombies in order to save his own skin; Dário's passivity towards violent behaviour in the tavern and Sam hurting Nancy or not opening the tavern's door, this way preventing Nancy and Lúcio from reaching safety when they were being attacked by zombies.

Women, on the other side, represent a different type of monstrosity, particularly Ana, played by Sofia Aparício, a well-known model in Portugal. As a standard of beauty, she is an interesting choice to interpret a zombie, who represents the decaying body and reminds us of our own mortality, «their unnatural state makes them a poignant representation of mortality itself, an uncanny memento mori that threatens the hapless living with either 
death or transformation to undeath»(Bishop, 2010: 108). Furthermore, she will be responsible for Lúcio's death and consequent transformation into a zombie. Nancy, who is also played by a well-known actress in Portugal, São José Correia, personifies the violence exercised by men on women, especially because of Sam the Tavern Costumer and, finally, Lúcio, who upon seeing no other alternative pushes her to the zombie horde to save himself.

In this context, I'll See You in My Dreams questions the division between humans and monsters. The tavern or the domestic places, like Lúcio's house, are not much different from the forest, since in both places horrific deeds are put into practice. This is particularly true if we consider zombie-Ana being locked in the basement.

The final scene of I'll See You in My Dreams is representative of the way the division between human beings and monsters is blurred. After freeing himself from the zombie horde, Lúcio confronts Ana, who will transform him into a zombie. Looking at her, Lúcio is fixated on Ana's image before becoming a zombie, when she was beautiful and her body was not decayed. This glimpse into the past symbolises a place and time when the monstrous zombies had not taken over. Lúcio is briefly distracted by this dreamy image - being dreams the only place where he can return to his former life -, that soon becomes a nightmare, as zombie-Ana bites Lúcio, who now becomes literally the monster he had been fighting against. In the end, the film presents us with a circular story, in view of the fact that it brings us to the opening scene, but this time Lúcio is presented as the zombie he initially kills in the forest. Instead of commenting on how much he hates the zombies, zombie-Lúcio now says: The thing I hate the most are the fucking humans.

The final twist with Lúcio is that he becomes irrelevant in the world he inhabits and pays for his monstrous acts towards both Nancy and Ana. Moreover, Lúcio embodies the ease with which humans can quickly be transformed into monsters, figuratively - for their actions - and literally - because of the zombie bite -, which confirms humanity's predisposition for monstrosity. I'll See You in My Dreams, like many other zombie narratives, uses the zombie as a «monstrous tabula rasa» (Muntean \& Payne, 2009: 240) to comment on human actions. More than paying homage to the masters of horror, the short-film is the product of the rise of the monster zombie, a creature of the $21^{\text {st }}$ century cinema that has been adopted as a metaphor for contemporary fears and anxieties. At the same time, it is also a critique on a world concerned primarily with basic instincts and survival, with the zombie embodying our own monstrosity, not only because it highlights our actions as humans, but also our faults as such. 


\section{BIBLIOGRAPHY:}

Ackermann, Hans-W. and Jeanine Gautier (1991): «The Ways and Nature of the Zombi», The Journal of American Folklore, vol. 104, no. 414 (Autumn), pp. 466494.

$<$ http:/ /dx.doi.org/10.2307/541551>

Asma, Stephen (2009): On Monsters. An Unnatural History of Our Worst Fears, Oxford University Press, Oxford, NY.

Balun, Chas (1996): Lucio Fulci: Beyond the Gates, Blackest Heart Books, San Leandro, California.

Bildhauer, Bettina \& Mills, Robert (2003): «Introduction: Conceptualizing the Monstrous», in Bettina Bildhauer and Robert Mills (eds.), The Monstrous Middle Ages, University of Toronto Press, Toronto and Buffalo, pp. 1-27.

Bishop, Kyle (2006): «Dead Man Still Walking: Explaining the Zombie Renaissance, Journal of Popular Film and Television, pp. 17-25.

$<$ http:/ /dx.doi.org/10.3200/jpft.37.1.16-25>

(2006): «Raising the Dead», Journal of Popular Film and Television, pp. 196-205.

<http:/ /dx.doi.org/10.3200/jpft.33.4.196-205>

(2010): American Zombie Gothic: The Rise and Fall (and Rise) of the Walking Dead in Popular Culture, McFarland \& Co, Inc., Jefferson, NC.

CoHen, Jeffrey Jerome (ed.) (1996): Monster Theory: Reading Culture, University of Minnesota Press, Minneapolis.

Dendle, Peter, (2010): The Zombie Movie Encyclopedia, McFarland \& Co, Inc., Jefferson, NC.

Glenn, Kay \& Brugues, Alejandro (2012): Zombie Movies: The Ultimate Guide, Chicago Review Press, Chicago.

Hickman, Leo (2010): «The Forest: From Fairytales to Horror Films», in The Guardian, 2010, available at <http://www.theguardian.com/culture/2010/oct/29/forest-fairytales-horror-films $>$ [15/05/2015].

LAuro, Sarah Juliet and Karen Embry (2008): «A Zombie Manifesto: The Nonhuman Condition in the Era of Advanced Capitalism», Boundary, 2, 35:1, pp. 85-108. <http: / / dx.doi.org/10.1215/01903659-2007-027>

Le Goff, Jacques (1992): «The Wilderness in the Medieval West», in The Medieval Imagination, Arthur Goldhammer [trad.], The University of Chicago Press, Chicago, London, pp. 47-59.

MacCormack, Patricia (2004): «Great Directors: Lucio Fulci», Senses of Cinema, no. 31, 2004, available in <http://sensesofcinema.com/2004/great-directors/fulci/> [15/05/2015].

MAIo, Kathi (2007): «Mission Accomplished at the Zombie Jamboree», Fantasy and Science Fiction, October/November, pp. 192-196.

Mittman, Asa Simon (2012): «Introduction: The Impact of Monsters and Monster Studies», in Asa Simon Mittman and Peter J. Dendle (eds.), The Ashgate Research Companion to Monsters and the Monstrous, Ashgate, Farnham, Burlington, pp. $1-14$. 
Muntean, Nick \& Thomas Payne (2009): «Attack of the Living Dead: Recalibrating Terror in the Post-September 11 Zombie Film», in Andrew Schopp and Matthew B. Hill (eds.), The War on Terror: September 9/11 and Beyond, Farleigh Dickinson, Madison, Teaneck, pp. 239-259.

Oliveira, Adriano Messias de (2013): «I'll See You in My Dreams: o morto-vivo como pesadelo na aldeia portuguesa», in Ana Catarina Pereira e Tito Cardoso e Cunha (eds.), Geração Invisível: Os novos cineastas portugueses, Livros LabCom, Covilhã, pp. 27-51.

Rowan, Terry (2012): The Book of the Undead: A Zombie Film Guide, Terry Rowan, Perfect-Bound Paperback.

Schорт, Andrew and Matthew Hill B (2013): «Introduction: The Curious Knot», in Andrew Schopp and Matthew B. Hill (eds.), The War on Terror: September 9/11 and Beyond, Farleigh Dickinson, Madison, Teaneck, pp. 11-45.

UZI Magazine (2004): «Filipe Melo em discurso directo», UZI magazine, 2004, available in <http: / / www.uzimagazine.com/artigos_detalhe.php?id=100> [15/05/2015].

Williams, David (1999): Deformed Discourse. The Function of the Monster in Mediaeval Thought and Literature, University of Exeter Press, Exeter.

Youngs, Deborah \& Simon Harris (2003): «Demonizing the Night in Medieval Europe: A Temporal Monstrosity?», in Bettina Bildhauer and Robert Mills (eds.), The Monstrous Middle Ages, University of Toronto Press, Toronto and Buffalo, pp. 134-154.

FILMOGRAPHY:

FulcI, Lucio (dir.) (1980): Paura nella città dei morti viventi (City of the Living Dead), Dania Film/Medusa Distribuzione/National Cinematografica, Italy. (1981): ...E tu vivrai nel terrore! L'aldilà (The Beyond), Fulvia Film, Italy. (1981): Quella villa accanto al cimitero (House by the Cemetery), Fulvia Film, Italy.

Guedes, Tiago \& Frederico Serra (dirs.) (1981): Coisa Ruim, Madragoa Filmes, Portugal.

Vivas, Miguel (dir.) (2003): I'll See You in My Dreams, Pato Profissional Limitada, Portugal. 